\title{
Detection of a New Luteovirus in Imported Nectarine Trees: A Case Study to Propose Adoption of Metagenomics in Post-Entry Quarantine
}

\author{
Sudeep Bag, Maher Al Rwahnih, Ashley Li, Asaul Gonzalez, Adib Rowhani, Jerry K. Uyemoto, and Mysore R. Sudarshana \\ First, second, and fifth authors: Department of Plant Pathology, University of California, One Shields Avenue, Davis 95616; and third, fourth, \\ sixth, and seventh authors: U.S. Department of Agriculture, Agricultural Research Service, Department of Plant Pathology, University of \\ California, One Shields Avenue, Davis 95616.
}

Accepted for publication 27 February 2015.

\begin{abstract}
Bag, S., Al Rwahnih, M., Li, A., Gonzalez, A., Rowhani, A., Uyemoto, J. K., and Sudarshana, M. R. 2015. Detection of a new luteovirus in imported nectarine trees: A case study to propose adoption of metagenomics in post-entry quarantine. Phytopathology 105:840-846.

In spring 2013, 5-year-old nectarine (Prunus persica) trees, grafted on peach rootstock Nemaguard, were found stunted in a propagation block in California. These trees had been propagated from budwood of three nectarine cultivars imported from France and cleared through the post-entry quarantine procedure. Examination of the canopy failed to reveal any obvious symptoms. However, examination of the trunks, after stripping the bark, revealed extensive pitting on the woody cylinder. To investigate the etiological agent, double-stranded RNA was extracted from bark scrapings from the scion and rootstock portions, and a cDNA library was prepared and

sequenced using the Illumina platform. BLAST analysis of the contigs generated by the de novo assembly of sequence reads indicated the presence of a novel luteovirus. Complete sequence of the viral genome was determined by sequencing of three overlapping cDNA clones generated by reverse transcription-polymerase chain reaction (RT-PCR) and by rapid amplification of the $5^{\prime}$ - and $3^{\prime}$-termini. The virus genome was comprised of 4,991 nucleotides with a gene organization similar to members of the genus Luteovirus (family Luteoviridae). The presence of the virus, tentatively named Nectarine stem pitting-associated virus, was confirmed in symptomatic trees by RT-PCR. Discovery of a new virus in nectarine trees after postentry quarantine indicates the importance of including (i) metagenomic analysis by next-generation sequencing approach as an essential tool to assess the plant health status, and (ii) examination of the woody cylinders as part of the indexing process.
\end{abstract}

As stone fruit breeders develop elite cultivars and interspecies hybrids, they can be released all over the world for commercial production. While true seeds remain the propagation material of choice for most annual crops, perennial crops such as citrus, grapevines and stone fruits are propagated clonally to maintain characteristics of the cultivar. However, such introductions and exchanges of vegetative plant materials carry the risk of introducing pests and diseases into new locations. Most countries have established protocols to permit the introduction of plant materials through post-entry quarantine. Protocols at the destination generally include examination of accompanying certification and test reports of pathogens known to exist in the country of origin. This is followed by laboratory diagnostic assays and bioassays on indicator hosts grown in isolation at the destination (Gergerich et al. 2015; Rowhani et al. 2005; Waterworth and White, 1982).

Apricot (Prunus armeniaca), nectarine and peach ( $P$. persica), plum and prune $(P$. cerasifera, $P$. domestica), and sweet cherry ( $P$. avium) constitute the major stone fruits grown in California (Strand, 1999). These, along with almonds (P. dulcis), are susceptible to several viruses, viroids, and phytoplasmas. Among viruses infecting stone fruits, Prunus necrotic ringspot virus (genus Ilarvirus, family Bromoviridae), the causal agent of infectious bud failure, calico in almonds, and rugose disease in cherries, is distributed worldwide (Oliver et al. 2009). However, Plum pox virus (PPV; family Potyviridae) is by far the most destructive virus, though largely restricted to Europe and Asia (Levy et al. 2000). Despite stringent quarantine measures, PPV was detected in Michigan, New

Corresponding author: M. R. Sudarshana;

E-mail address: mysore.sudarshana@ars.usda.gov

http://dx.doi.org/10.1094/PHYTO-09-14-0262-R

This article is in the public domain and not copyrightable. It may be freely reprinted with customary crediting of the source. The American Phytopathological Society, 2015.
York, and Pennsylvania in the United States. It was also detected in Nova Scotia and Ontario provinces in Canada. The cost of eradication of infected trees and trees in the buffer zones in Canada and the United States was close to $\$ 220$ million (Lehnert 2012). In Pennsylvania, trees in $>1,600$ acres were destroyed to eliminate the threat of PPV due to prevalence of its aphid vectors in North America (Gildow et al. 2004; Lehnert, 2012; Scorza et al. 2007).

Most quarantine programs rely on the state of knowledge of viruses and virus-like agents, and the availability of bioassays on indicator plants and detection assays using serological or molecular diagnostic tools (Rowhani et al. 2005). Quarantine measures rarely failed as the program required a mandated monitoring of plants grown in isolation for the appearance of suspicious symptoms due to pathogens not previously described and elimination of such plants.

In this study, we report a stem pitting disease in trees of nectarine cultivars from France, cleared through post-entry quarantine procedures, associated with a novel luteovirus as revealed by next-generation sequencing (NGS) approach.

\section{MATERIALS AND METHODS}

Plant sources. In the summer of 2013, 5-year-old trees of three nectarine cultivars, SF04.522, SF05.211, and SF06.176, grafted on Nemaguard rootstock, were found stunted in a scion source block. These trees were examined for foliar symptoms and markings on the woody cylinders of scion and rootstock. Affected trees were uprooted and the trunks were autoclaved for $5 \mathrm{~min}$. Bark was stripped, and the woody cylinders were examined for stem markings.

Double-stranded RNA extraction and deep sequencing. Cambial scrapings from the inside of the bark tissue and surface of the woody cylinder were collected from the scion and rootstock portions. These scrapings were frozen in liquid nitrogen and stored at $-70^{\circ} \mathrm{C}$ until further use. 
Double-stranded (ds)RNA was extracted from $30 \mathrm{~g}$ of scraping, as described by Routh et al. (1998), without nuclease (DNase and RNase) treatment. Two composite samples, designated S1 and S2, were used for dsRNA extraction. S1 was comprised of the rootstock portion of three symptomatic trees, one each of cultivars SF04.522, SF05.211, and SF06.176. S2 was comprised of the scion portion close to the graft unions of two symptomatic trees, one each of cultivars SF04.522 and SF05.211. The cDNA libraries were prepared using SuperScript III (Life Technologies Inc., Grand Island, NY) primed with random hexamers and amplified using GenomePlex complete whole genome amplification kit (WGA2) (Sigma Aldrich, St. Louis, MO) following the manufacturer's instructions with the exception of the fragmentation step. The amplified DNA was purified using a polymerase chain reaction (PCR) cleanup kit (Sigma Aldrich) and quantified as described by Al Rwahnih et al. (2009).

Sequencing was performed by Eureka Genomics Corporation (Hercules, CA) on HiSeq2000 (Illumina Inc., San Diego, CA). Sequence data were generated from 50 cycle single end reads and subjected to de novo assembly by proprietary assembly software of Eureka Genomics. For each sample, contigs of a minimum of 100 bases were generated after clipping the adapter sequences.

Bioinformatics analysis. The nucleotide sequences of assembled contigs were subjected to BLASTN and BLASTX analyses using a CLC Genomics Workbench (Qiagen Inc., Valencia, CA). Contigs were first analyzed by BLAST using the MEGABLAST option (www.ncbi. nlm.nih.gov). Contigs that still remained unknown after MEGABLAST were analyzed by BLASTN with word size set to 7 or by BLASTX to find hits in the public domain databases. A draft sequence using the sequences of overlapping contigs was generated.

Detection of a new luteovirus in nectarine trees. During fall 2013 and spring 2014, bark, leaf, and petiole samples were collected from symptomatic and asymptomatic nectarine trees. Bark samples from one of the nectarine trees used for metagenomics analysis that had been stored at $-70^{\circ} \mathrm{C}$ and from a peach tree in an experimental orchard were used as positive and negative controls, respectively. Total RNA was extracted and a two-step reverse transcription (RT)-PCR assay was performed using SuperScript III (Life Technologies Inc.), GoTaq DNA polymerase (Promega Inc., Madison, WI) and detection primers NSPaVR and NSPaVF. Firststrand cDNA was synthesized using SuperScript III and NSPaVR at $50^{\circ} \mathrm{C}$ as per manufacturer's instructions. Subsequent amplification by PCR was performed in a $25-\mu$ l reaction volume with 1 unit of GoTaq DNA polymerase, $1 \times$ GoTaq DNA polymerase buffer, $1.25 \mu \mathrm{l}$ of $0.1 \mathrm{M}$ DTT, $2 \mu \mathrm{l}$ of $25 \mathrm{mM} \mathrm{MgCl} 2,1 \mu \mathrm{l}$ of $10 \mathrm{mM}$ dNTPs, $0.5 \mu \mathrm{l}$ of $10 \mu \mathrm{M}$ each forward and reverse primers, and $5 \mu$ of $10 \%$ PVP-40. The PCR profile was one cycle of initial denaturation for $1 \mathrm{~min}$ at $95^{\circ} \mathrm{C}$, followed by 40 cycles of denaturation at $94^{\circ} \mathrm{C}$ for $30 \mathrm{~s}$, annealing at $56^{\circ} \mathrm{C}$ for $30 \mathrm{~s}$, and extension at $72^{\circ} \mathrm{C}$ for $60 \mathrm{~s}$, followed by final extension of $10 \mathrm{~min}$ at $72^{\circ} \mathrm{C}$. The amplified product was cloned using TOPO-TA cloning kit and the sequence of the cloned product was verified by Sanger sequencing using M13-forward and M13-reverse primers.

Determination of the complete sequence of a new virus. Primers were designed based on the assembled draft sequence (Table 1) and custom ordered from Life Technologies. Total RNA was extracted from sample $\mathrm{S} 1$, which had been stored at $-70^{\circ} \mathrm{C}$, using a Plant RNeasy kit (Qiagen Inc.) with modifications suggested by MacKenzie et al. (1997). The extracted RNA was stored at $-70^{\circ} \mathrm{C}$ until further use.

The presence of the new virus was first verified by RT-PCR. Detection primers NSPaVF and NSPaVR (Table 1) were designed based on the draft sequence obtained by NGS, and RT-PCR was performed using total RNA on an Eppendorf Master Gradient cycler (Eppendorf Inc. Hauppauge, NY)., The amplified product was analyzed on a $1.2 \%$ agarose gel in $1 \times$ Tris-acetate EDTA (TAE) buffer by electrophoresis, stained by ethidium bromide, and visualized on an UV transilluminator (UVP Inc., Upland, CA). Amplified products were cloned using a TOPO-TA cloning kit (Life Technologies Inc.) and the sequence of the cloned product was verified by Sanger sequencing using the primers used for amplification at the University of California (UC) Davis sequencing facility (http://dnaseq.ucdavis.edu).

Three overlapping cDNA clones of 1,968, 2,080, and 1,498 nt were generated by RT-PCR, using primer pairs NSPaVF1 and NSPaVR, NSPaVF and NSPaVR3, and NSPaVF3 and NSPaVR4 (Table 1), respectively. After reverse transcription using SuperScript III, amplicons were amplified with the extension time of $1 \mathrm{~min}$ for each 1-kb target. Amplified products were cloned using TOPO-TA Cloning kit and sequenced at the UC Davis sequencing facility using M13-forward and M13-reverse primers, and additional primers designed to walk over the clones.

The $5^{\prime}$ and $3^{\prime}$ termini of viral RNA were determined by rapid amplification of the cDNA ends (RACE) (Domier et al. 2002). For the 5' terminus, cDNA was synthesized from total RNA using primer NSPaVR5 (Table 1). The cDNA was purified using a PCR purification kit (Qiagen Inc.) and tailed separately with dATP and dGTP using terminal deoxynucleotidyl transferase (New England Biolabs Inc., Ipswich, MA). For the dATP tailed cDNA, 5' terminus was amplified by PCR using primers RB259T12 and NSPaV-251R, followed by a nested PCR using primers GVGF1 and NSPaV-173R (Table 1). For dGTP tailed cDNA, the $5^{\prime}$ terminus was amplified by PCR using primers RB260C11 and NSPaV-251R, followed by a nested PCR using primers GVGR1 and NSPaV-173R (Table 1).

The $3^{\prime}$ terminus was determined by using the First Choice RLMRACE kit (Life Technologies Inc.) following the manufacturer's instructions. Total RNA was ligated with the adapter RNA using RNA ligase and cDNA was synthesized and amplified by RT-PCR

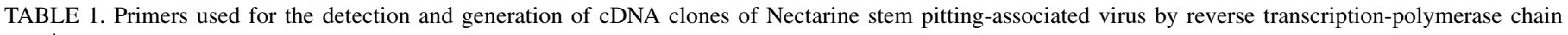
reaction

\begin{tabular}{|c|c|c|c|}
\hline Primer name & Nucleotide sequence $5^{\prime}-3^{\prime}$ & Priming position $^{\mathrm{a}}$ & Comments \\
\hline NSPaVF & AGACTAAAATTCAATGAAAAGA & $1646-1667$ & Detection primer \\
\hline NSPaVR & TTTCACAAATGATAACACAAT & $2085-2105(\mathrm{C})$ & Detection primer \\
\hline NSPaVF1 & TTTCGATCTCCTTATTTCTGCC & $137-158$ & \\
\hline NSPaVF3 & TCAATGTACAAGTGGGAGGATGA & $3508-3530$ & \\
\hline NSPaVF4 & AAACAAGAGATACCAGTTTACCT & $4839-4860$ & $3^{\prime}$ gene-specific inner primer \\
\hline NSPaVF8 & GGTTCCAACTATTGCTCC & $4753-4771$ & $3^{\prime}$ gene-specific outer primer \\
\hline NSPaVR3 & CGGTTGACGTTGTACGCTACAC & $3704-3725(\mathrm{C})$ & \\
\hline NSPaVR4 & TTCGCCAGAGCATCTGCACA & $4947-4966(\mathrm{C})$ & \\
\hline NSPaVR5 & TTGCСТСТСТСАТTCTCTTG & $641-660(C)$ & \\
\hline NSPaV-173R & TTCGAAGCACTCTGCCA & $267-284(\mathrm{C})$ & \\
\hline NSPaV-251R & САТСАТССАССТССТССТСТТG & 309-327 (C) & \\
\hline RB259T12 & CTCGTCGCATTTGATAGA(T) $)_{12}$ & - & Adapter for $5^{\prime}$ poly $(\mathrm{dA})$ \\
\hline RB260C11 & ACTGACAAGGCCTACTACG $(\mathrm{C})_{11}$ & - & Adapter for $5^{\prime}$ poly $(\mathrm{dG})$ \\
\hline GVGF1 & CTCGTCGCATTTGATAGA & - & Adapter for RB259T 12 \\
\hline GVGR1 & ACTGACAAGGCCTACTACG & - & Adapter for $\mathrm{RB} 260 \mathrm{C}_{11}$ \\
\hline
\end{tabular}

a The priming position is with respect to GenBank accession KP638562. (C) represents complementary sequence. 
using SuperScript III and GoTaq DNA polymerase as described above. The 3' terminus was amplified using the primer NSPaVF8 and $3^{\prime}$ RACE outer primer, followed by a nested PCR using the primer NSPaVF4 and RACE inner primer.

The products obtained from RACE were cloned using TOPO-TA cloning kit. Nine clones of the 5' RACE product and five clones of the $3^{\prime}$ RACE product were sequenced and a consensus sequence was generated.

The complete sequence of the virus was assembled from the nucleotide sequences of three overlapping RT-PCR clones and clones obtained from $5^{\prime}$ and $3^{\prime}$ end RACE. The sequence was further verified by comparing with the consensus sequence obtained from contigs generated from Illumina reads.

Phylogenetic analysis. The phylogenetic relationship of the new virus was determined using the amino acid sequence of the coat protein $(\mathrm{CP})$ and RNA dependent RNA polymerase (RdRp) genes, and the complete genome sequences of members of the family Luteoviridae available in GenBank. The evolutionary relationship of the new virus was determined by aligning the sequences using MUSCLE and the phylogenetic trees were generated using MEGA 6 by the neighbor joining method (Tamura et al. 2013).

\section{RESULTS}

Symptomatology. In a scion propagation block, several 5-yearold trees of three nectarine cultivars SF04.522, SF05.211, and SF06.176, originating from France and grafted on Nemaguard peach rootstock, were stunted when compared with the trees of other nectarine cultivars similarly propagated. Foliar symptoms were not apparent and bark on scaffolds did not indicate any obvious trunk disorders. When a punch hole was made and the bark was removed, the woody cylinder of the trunk showed extensive pitting (Fig. 1A). A tree from each of the three nectarine cultivars was uprooted and the trunk portion covering the graft union was further examined after autoclaving and stripping of the bark. Pitting was restricted to the woody cylinders of the scion but was absent on the rootstock portion. Subsequent propagation of budwood from the propagation block produced trees that were also pitted (Fig. 1B).

Metagenomic analysis of the RNA by Illumina sequencing. The identity of the etiological agent(s) associated with stem pitting was investigated by metagenomics analysis. The Illumina reads obtained from sequencing the cDNA libraries, prepared using the nucleic acid extracts from the scion and rootstock portion, yielded nucleotide sequences of a total of 1.6 and $1.7 \mathrm{~GB}$, respectively. In BLASTN searches with a word size of 7, two contigs, S1-106 (745 nt) from sample $\mathrm{S} 1$ and a 224-nucleotide region from a contig S2-83 (1,219 nt) from sample S2, showed homology with the genome sequence of Soybean dwarf virus (SDV; GenBank AB038149.1) with identity scores of 69 and $73 \%$, respectively. Contig S2-83 also showed homology with the RdRp gene of SDV in BLASTX. Several other contigs also matched with the RdRp of members of the family Luteoviridae. Five contigs from $S 1$ and $S 2$ were assembled into a stretch of 4,925 nt that constituted most of the genome of a novel luteovirus species, tentatively called Nectarine stem pitting-associated virus (NSPaV) (Fig. 2A).
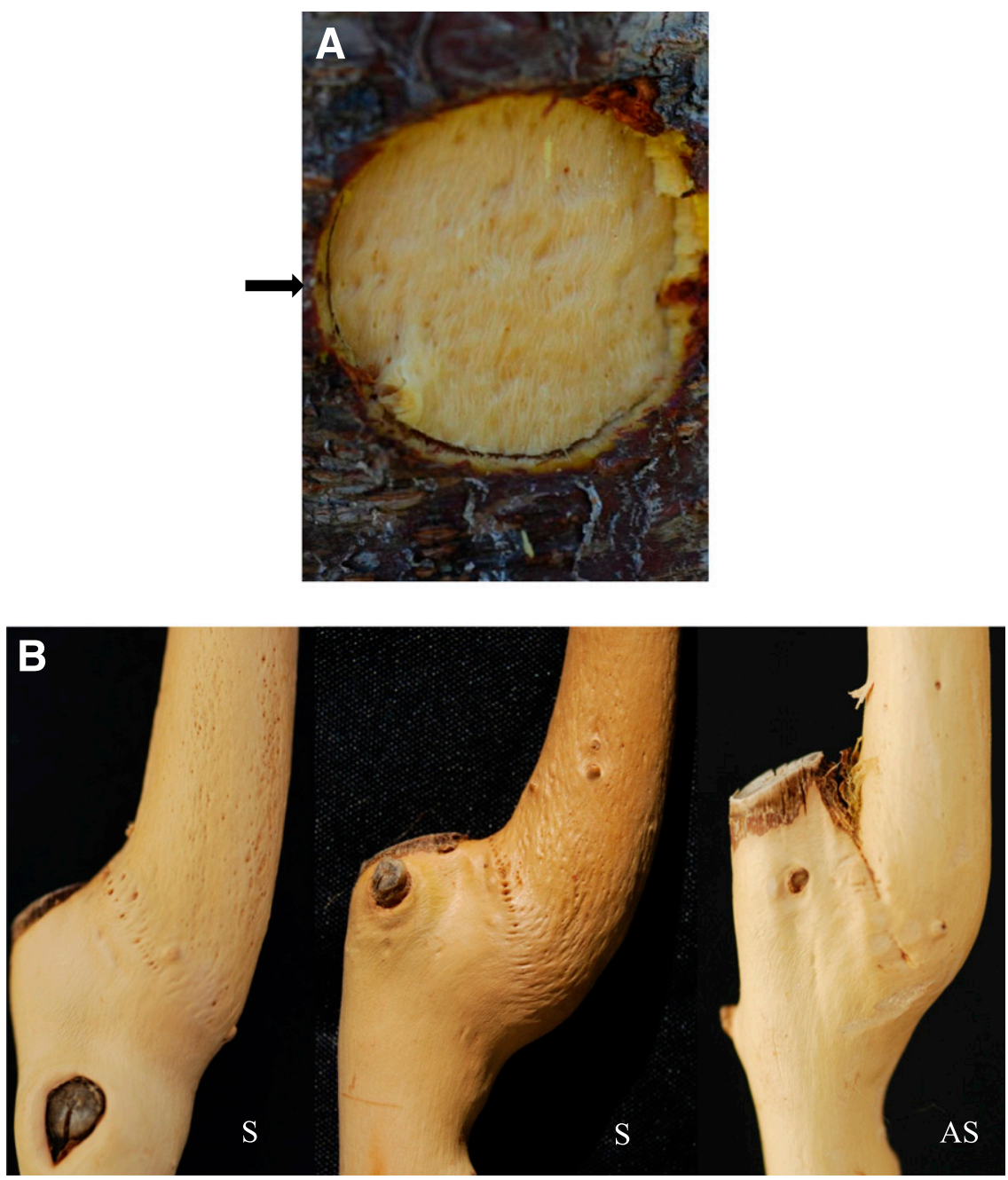

Fig. 1. A, Trunk of a nectarine tree of cultivar SF05.211 showing stem pitting on the woody cylinder after removal of the bark and arrow indicates necrotic islands in the bark. B, Young trees in a propagation block showing pitting symptoms at graft union and scion trunks: S, symptomatic; AS, asymptomatic. 
Detection of NSPaV in nectarine trees. The association of NSPaV in symptomatic nectarine trees was next examined by RTPCR analysis on total RNA extracts using the detection primers NSPaVF and NSPaVR (Table 1). A band of expected size (459 bp) was detected by RT-PCR using total RNA from bark sample of a tree used for metagenomic analysis (lane 2, Fig. 3A). NSPaV was also detected in RNA extracts of bark from symptomatic 6-year-old nectarine trees, but not in RNA extracts from asymptomatic nectarine trees and a healthy peach tree from an experimental orchard. However, one symptomatic tree failed to test positive for NSPaV (lane 5, Fig. 3). The RNA extracts from leaf and petiole samples behaved similar to the extract from bark tissue (data not shown).

Genome organization and analysis. The NGS sequence was verified by sequencing three overlapping RT-PCR products, generated using specific primers to NSPaV (Fig. 2B). The complete genome sequence of NSPaV was assembled after determining the $5^{\prime}$ and $3^{\prime}$ ends of viral RNA. The complete linear single stranded RNA genome was 4,991 $\mathrm{nt}$ in length and contained four open reading frames (ORFs) in positive sense (Fig. 2C). The genome organization was similar to that of members of the genus Luteovirus (family Luteoviridae). The full sequence of NSPaV has been submitted to the National Center for Biotechnology Information database as GenBank accession number KP638562.

The sequence of the $5^{\prime}$ end was determined by performing separate dATP and dGTP tailing reactions. Both reactions predicted the same 5 ' end terminus with an additional $131 \mathrm{nt}$ not found in the preliminary analysis of the NGS data. A conserved element GUAAAG, found in the genomic RNA of most luteoviruses at nucleotide position 2 to 7 (Domier et al. 2002), was located at the 5' end and also at position 2631. The first element was $130 \mathrm{nt}$ upstream of the start codon of ORF 1 and 2, while the second was $113 \mathrm{nt}$ upstream of the start codon of ORF 3.

The untranslated region at the 3 ' terminus, as revealed from the cloned amplified products obtained by RACE and RT-PCR, was $671 \mathrm{nt}$ in length. Further analysis of the genomic RNA indicated the presence of four putative ORFs in the sense orientation. The ORFs 1 (nucleotides 132 to 1118 ) and 2 (nucleotides 1117 to 2674) could encode for 334 and 519 amino acids long P1 and P2 proteins, respectively, which together would form the RdRp complex. ORF 2 was predicted to be synthesized by a ribosomal frame shift during translation of ORF 1. A heptanucleotide sequence GGGUUUUU was also found at the junction of ORFs 1 and 2 (Domier et al. 2002). Another conserved element with the sequence CCCCUUUUUCU CUUUUGGG found in most luteoviruses and known to be responsible for the -1 ribosomal frameshift translation was located $30 \mathrm{nt}$ downstream of the heptanucleotide in NSPaV (Domier et al. 2002).

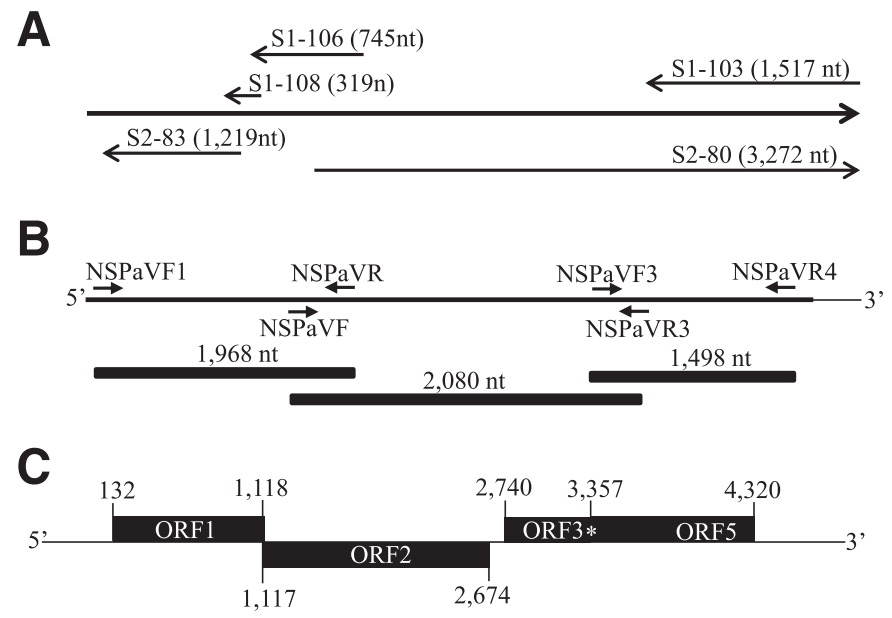

Fig. 2. A, Mapping of contigs produced from Illumina sequence reads, B, position of overlapping cDNA clones, and $\mathbf{C}$, predicted genome organization of Nectarine stem pitting associated virus $(\mathrm{NSPaV})$. * represents the leaky stop codon at the end of open reading frame 3 (ORF3).
After a small intergenic region (IGR) of 65 nucleotides (nucleotides 2675 to 2739), ORFs 3 and 5 (nucleotides 2740 to 4325) were identified. The ORF 3 was predicted to encode the CP and a fusion protein predicted to be the factor responsible for insect transmission. This fusion protein is believed to be expressed by read-through translation of the leaky stop codon (UGA) located between ORFs 3 and 5 at nucleotide 3357. The stop codon is followed by five tandem repeats of the motif CCN NNN at $12 \mathrm{nt}$ downstream of the CP stop codon.

Phylogenetic analysis of the genome sequence of NSPaV and members of the family Luteoviridae available in GenBank indicated that $\mathrm{NSPaV}$ clustered with members of the genus Luteovirus (Fig. 4A). This relationship was also found when the predicted amino acid sequences of the CP (Fig. 4B) and RdRp (data not shown) were analyzed. Within the genus Luteovirus, NSPaV clustered close to Rose spring dwarf-associated virus (RSDaV).

\section{DISCUSSION}

With ever increasing globalization and agricultural trade, pathogens from one part of the world can be introduced into other geographic regions via importation of contaminated propagation material that may lead to new disease outbreaks of economic consequences. Despite strict regulatory measures, several destructive pathogens from the Old World were found in the New World in recent years (Rodoni 2009). Plum pox virus (Levy et al. 2000, Thompson et al. 2001), Tomato yellow leaf curl virus (Polston et al. 1999), and Liberibacter asiaticus (Manjunath et al. 2008), and Asian soybean rust causing fungus Phakospora pachyrhizi (Schneider et al. 2005) are some pathogens recently introduced into the New World. Several viruses that have been recognized in woody perennials in the United States were either latent, e.g., Grapevine leafroll-associated virus 2 strain RG in table grape cultivar Red Globe (Uyemoto et al. 2001), or those that were simply not recognized, e.g., Grapevine red blotch-associated virus, because the disease symptoms were not easily distinguishable despite their wide distribution (Al Rwahnih et al. 2013; Krenz et al. 2014; Sudarshana et al. 2015).

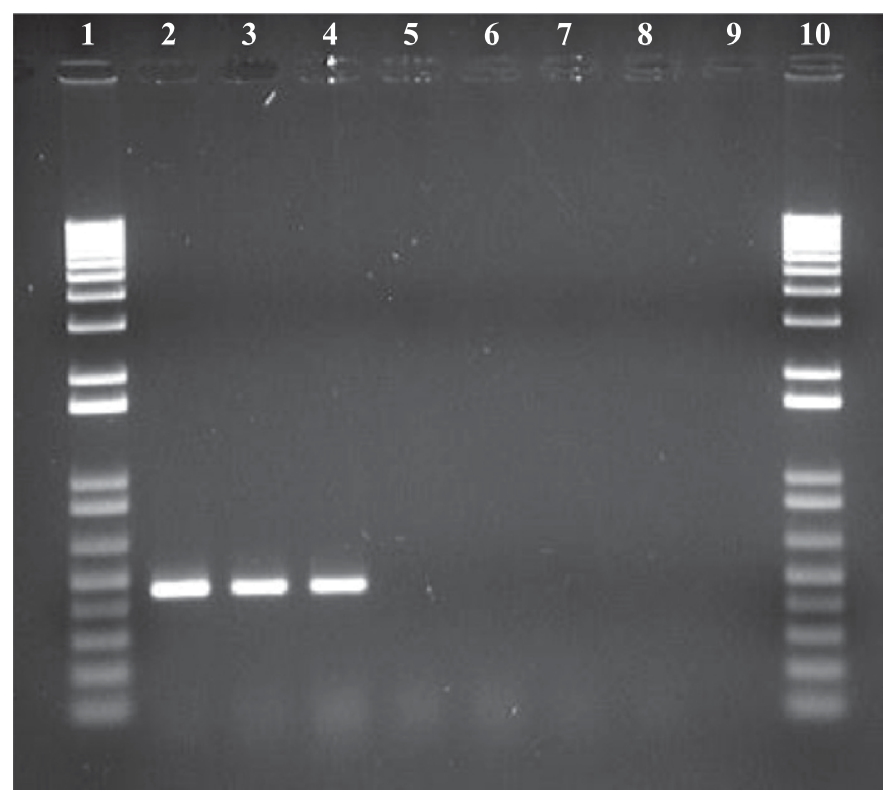

Fig. 3. Detection of Nectarine stem pitting associated virus (NSPaV) by reverse transcription-polymerase chain reaction on the RNA extracts from bark tissue of 6-year-old mature trees. Lanes 1 and 10,1 kb Plus DNA ladder (Invitrogen Inc., Carlsbad, CA); lane 2, SF05.211 used for metagenomic analysis; lanes 3 to 5 , symptomatic nectarine trees; lanes 6 and 7, healthy nonsymptomatic trees; lane 8 , healthy peach from an experimental orchard; and lane 9, water control. 
In a propagation block in California, 5-year-old nectarine trees propagated from imported budwood onto seedling rootstock Nemaguard, after post-entry quarantine clearance, were found to be stunted. After removal of the bark, it was found that these trees had developed pitting on the woody cylinder of the scion (Fig. 1A). In Prunus spp., stem pitting has been recognized in peaches infected by Tomato ringspot virus (ToRSV) (Barrat et al. 1968), and in apricots and plums infected by Plum bark necrosis stem-pitting
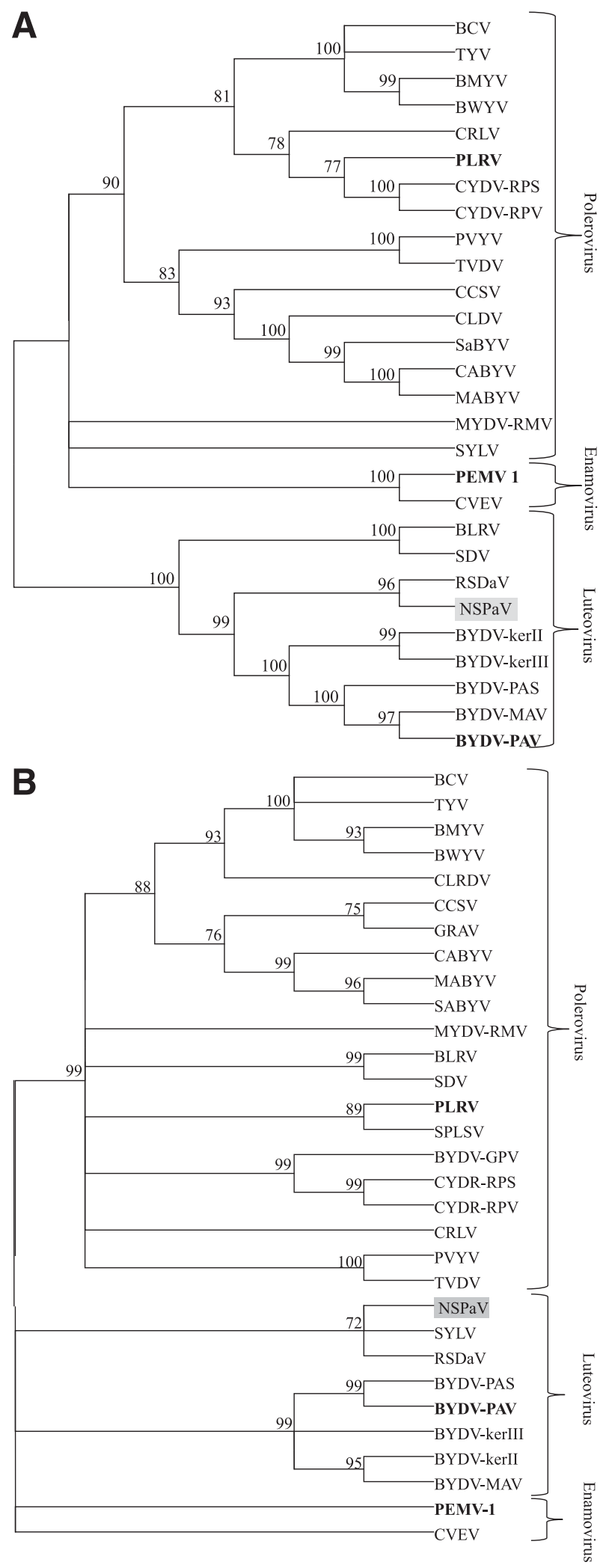

associated virus (PBNSPaV) (Abou Ghanem-Sabanadzovic et al. 2001; Marini et al. 2002). A stem pitting disease has also been described in sweet cherry orchards in the United States and Canada. However, a causal agent has not been reported in these trees (Zhang et al. 1998). Initially, it was thought that the stem pitting symptoms noticed in the nectarine trees (Fig. 1) were due to infection by PBNSPaV or ToRSV. Laboratory assays for these two viruses, however, were negative. Even so, a viral association was suspected in the nectarine tees.

Recently, several new viruses have been identified by metagenomic analyses using NGS in woody plants (Al Rwahnih et al. 2009, 2012, 2013; Giampetruzzi et al. 2012; Loconsole et al. 2012; Zhang et al. 2011). We therefore conducted a metagenomic analysis on dsRNA extracts using Illumina sequencing. We preferred to use the dsRNA enriched fraction as opposed to total RNA (Stewart et al. 2014) or siRNA (Kreuze et al. 2009; Loconsole et al. 2012; Pantaleo et al. 2009) in part due to our recent success in discovering both DNA and RNA viruses using this fraction (Al Rwahnih et al. 2009, 2012, 2013) and also to reduce RNA of host origin. In this study, NGS data revealed a new luteovirus sequence. In searches by BLAST, the only plant virus sequence that was found was of NSPaV. When all available reads from NGS were assembled, a draft sequence of 4,925 bases was generated.

When examined by RT-PCR assays, the presence of NSPaV was confirmed in the RNA extract from symptomatic trees. However, one symptomatic tree did not test positive for NSPaV. This might be due to a low virus titer or genetic variability in the virus populations generally common in RNA viruses (Garcia-Arenal et al. 2001).

We next designed primers for amplification of overlapping cDNA clones and 5' and $3^{\prime}$ RACE, and the complete sequence of NSPaV was determined. The consensus sequence of the complete virus genome was 4,991 nt long (Fig. 2C).

Phylogenetic analyses using the nucleotide sequences of complete genome and amino acid sequences of $\mathrm{CP}$ indicated that $\mathrm{NSPaV}$ belonged to the genus Luteovirus in the family Luteoviridae (Fig. 4). Incidentally, the CP sequences of both Bean leafroll virus (BLRV) and Soybean dwarf virus (SDV) were found grouped under the genus Polerovirus (Fig. 4B). Yet, based on the RdRP and complete genome (Fig. 4A) sequences, these two viruses were

Fig. 4. Phylogenetic trees constructed using the A, complete genome nucleotide sequence of the members of the family Luetoviridae and $\mathbf{B}$, predicted amino acid sequences of coat protein by neighbor joining method algorithm provided in MEGA6. The number at each node indicates bootstrap values from 1,000 replicates. Branches with percent bootstrap values of $<70 \%$ were collapsed and the values below the branch are the percent support observed for the branches. The sequences of the following viruses retrieved from GenBank (accession numbers shown in parenthesis) for analysis include: Barley yellow dwarf virus-kerII (BYDV-kerII; NC_021481), Barley yellow dwarf virus-kerIII (BYDV-kerIII; KC559092), Barley yellow dwarf virus-MAV (BYDV-MAV; NC_003680), Barley yellow dwarf virus-PAS (BYDV-PAS; NC_002160), Barley yellow dwarf virus-PAV (BYDV-PAV; NC_004750), Bean leafroll virus (BLRV; NC_003369), Beet chlorosis virus (BCV; NC_002766), Beet mild yellowing virus (BMYV; NC_003491), Beet western yellows virus (BWYV; KM_076647), Carrot red leaf virus (CRLV; NC_006265), Cereal yellow dwarf virus-RPS (CYDV-RSP; NC_002198), Cereal yellow dwarf virus-RPV (CYDVRPV; EF521848), Chickpea chlorotic stunt virus (CCSV; NC_008249), Citrus vein enation virus (CVEV; HF679486), Cotton leafroll dwarf virus (CLDV; HQ827780), Cucurbit aphid-borne yellows virus (CABYV; JF939814), Maize yellow dwarf virus-RMV (MYDV-RMV; NC_021484), Melon aphid-borne yellows virus (MABYV; NC_010809), Pea enation mosaic virus 1 (PEMV-1; NC_003629), Pepper vein yellows virus (PVYV; AB594828), Potato leafroll virus (PLRV; KC456054), Rose spring dwarf-associated virus (RSDaV; NC_010806), Soybean dwarf virus (SDV; KJ786322), Suakwa aphid-borne yellows virus (SABYV; NC 018571), Sugarcane yellow leaf virus (SYLV; KF477093), Tobacco vein distorting virus (TYDV; NC_010732), and Turnip yellows virus (TYV; NC_003743). The virus names in bold are type members of the three genera in the family Luteoviridae. The tree position of Nectarine stem pitting associated virus $(\mathrm{NSPaV})$ is highlighted in gray. 
grouped under the genus Luteovirus. It appears that NSPaV is closely related to RSDaV reported from California (Salem et al. 2008a, 2008b). Incidentally, both NSPaV and RSDaV are the only two luteoviruses found so far in woody hosts of the family Rosaceae. In silico predictions indicated that the genome of NSPaV contained four ORFs, namely ORF 1, 2, 3, and 5. The ORFs 1 and 2 were predicted to encode the putative RdRp by the -1 translational frame shift strategy (Domier et al. 2002; Miller et al. 1995). The amino acid sequence of the putative RdRp of NSPaV showed $48 \%$ amino acid sequence identity with RSDaV. The ORFs 3 and 5 encode the putative coat protein and aphid transmission factors, respectively (Miller et al. 1995). It is noteworthy that in the NSPaV genome we could not find the equivalent of ORF 4 found in other luteoviruses (Salem et al. 2008b).

Luteoviruses are known to cause several economically important diseases in both dicots and monocots (Domier 2008). BLRV, Potato leafroll virus, and SDV are of economic importance in production agriculture. However, some luteoviruses, such as Groundnut rosette assistor virus (Murant 1990), are not known to cause any disease, but rather serve as "helper virus" for the transmission of other viruses that cause the disease.

Metagenomic analysis using NGS often reveals new viruses which may or may not be correlated with disease symptoms. For example, in investigations to determine the etiological agent of Syrah decline disorder of Syrah grapevines, a novel virus, Grapevine Syrah virus 1 (genus Marafivirus; family Tymoviridae), found by NGS, was not linked to symptomatic grapevines unequivocally (Al Rwahnih et al. 2009). In nectarine stem pitting disease, it is unclear if $\mathrm{NSPaV}$ is the causal agent or if another agent is involved. However, repeated analysis of the NGS data failed to reveal any other viruses or subviral agents. Nevertheless, because of the potential transmission of luteoviruses by aphids, further studies are needed to examine the role of NSPaV in causing stem pitting or other effects in other Prunus spp. It is also unknown whether the stem pitting disease has any economic impact on nectarine fruit production. Due to a very limited number of trees available in the propagation block, this could not be verified in the present study. Incidentally, the three nectarine cultivars SF04.522, SF05.211, and SF06.176 have been released for cultivation in Australia (http:// www.anfic.com.au/maturity-charts.html) and perhaps elsewhere. It remains to be seen if trees at these locations exhibit stem pitting and NSPaV infection.

Evaluation of woody perennial crops during post-entry quarantine does not mandate examination for wood markings. Symptomatic nectarine trees also had necrotic islands within the bark (Fig. 1A). It is highly recommended that quarantine protocols include such examinations. Also, current protocols only test for known pathogens prevalent in the country of origin and elsewhere. Because these tests are dependent on previous knowledge and availability of serological and molecular reagents for performing laboratory assays, it is highly desirable to have metagenomic analysis by NGS to account for unknown viruses and virus-like agents, and also to determine genetic variants of known viruses which may not be detected by PCR-based assays (Candresse et al. 2014). NGS-based protocols would also save a considerable amount of time and we believe these should be included in quarantine protocols. In the case of trees showing stem pitting, the source of the luteovirus can be the scion or rootstock. Because members of the family Luteoviridae are not known to be seed-transmitted and Nemaguard rootstocks are produced from seeds, the rootstock of affected nectarine trees are unlikely to be the source of NSPaV. Thus, it is likely that NSPaV was present in the scion budwood that was imported and cleared through quarantine.

This study highlights the need to apply metagenomic analysis by NGS in post-entry quarantine protocols. We anticipate findings from this study will lead to improved guidelines for handling trade and exchange of vegetatively propagated woody plants.

\section{ACKNOWLEDGMENTS}

This project was supported by USDA-ARS CRIS 5306-22000-014-00D. The authors acknowledge the cooperation of a grower for providing access to trees used in the study. Helpful comments by anonymous reviewers of this manuscript are much appreciated. Mention of a trademark, proprietary products, or vendor does not constitute guarantee or warranty of the product by the USDA, and does not imply its approval to the exclusion of other products and vendors that might also be suitable.

\section{LITERATURE CITED}

Abou Ghanem-Sabanadzovic, N., Mahboubi, M., Di Terlizzi, B., Sabanadzovic, S., Savino, V., Uyemoto, J. K., and Martelli, G. P. 2001. Molecular detection of a closterovirus associated with apricot stem pitting in Southern Italy. J. Plant Pathol. 83:125-132.

Al Rwahnih, M., Daubert, S., Golino, D., and Rowhani, A. 2009. Deep sequencing analysis of RNAs from a grapevine showing Syrah decline symptoms reveals a multiple virus infection that includes a novel virus. Virology 387:395-401.

Al Rwahnih, M., Dave, A., Anderson, M., Rowhani, A., Uyemoto, J. K., and Sudarshana, M. R. 2013. Association of a DNA virus with grapevines affected by red blotch disease in California. Phytopathology 103:1069-1076.

Al Rwahnih, M., Sudarshana, M. R., Uyemoto, J. K., and Rowhani, A. 2012. Complete genome sequence of a novel vitivirus isolated from grapevine. J. Virol. 86:9545.

Barrat, J. G., Mircetich, S. M., and Fogle, H. W. 1968. Stem pitting of peach. Plant Dis. Reptr. 52:91-94.

Candresse, T., Filloux, D., Muhire, B., Julian, C., Galzi, S., Fort, G., Bernardo, P., Daugrois, J. H., Fernandez, E., Martin, D. P., Varsani, A., and Roumagnac, P. 2014. Appearances can be deceptive: Revealing a hidden viral infection with deep sequencing in a plant quarantine context. PLoS One 9:e102945.

Domier, L. L. 2008. Luteoviruses. Pages 231-238 in: Encyclopedia of Virology. 3rd ed. B. W. J. Mahy and M. H. V. van Regenmortel, eds. Academic Press, San Diego, CA.

Domier, L. L., McCoppin, N. K., Larsen, R. C., and D’Arcy, C. J. 2002. Nucleotide sequence shows that Bean leafroll virus has a luteovirus-like genome organization. J. Gen. Virol. 83:1791-1798.

Garcia-Arenal, F., Fraile, A., and Malpica, J. M. 2001. Variability and genetic structure of plant virus population. Annu. Rev. Phytopathol. 39:157-186.

Gergerich, R. C., Welliver, R. A., Gettys, S., Osterbauer, N. K., Kamenidou, S., Martin, R. R., Golino, D. A., Eastwell, K., Fuchs, M., Vidalakis, G., and Tzanetakis, I. E. 2015. Safeguarding fruit crops in the age of agricultural globalization. Plant Dis. 99:176-187.

Giampetruzzi, A., Roumi, V., Roberto, R., Malossini, U., Yoshikawa, N., La Notte, P., Terlizzi, F., Credi, R., and Saldarelli, P. 2012. A new grapevine virus discovered by deep sequencing of virus- and viroid-derived small RNAs in Cv Pinot gris. Virus Res. 163:262-268.

Gildow, F., Damsteegt, V., Stone, A., Schneider, W., Luster, D., and Levy, L. 2004. Plum pox in North America: Identification of aphid vectors and a potential role for fruit in virus spread. Phytopathology 94:868-874.

Krenz, B., Thompson, J. R., McLane, H. L., Fuchs, M., and Perry, K. L. 2014. Grapevine red blotch-associated virus is widespread in the United States. Phytopathology 104:1232-1240.

Kreuze, J. F., Perez, A., Untiveros, M., Quispe, D., Fuentes, S., Barker, I., and Simon, R. 2009. Complete viral genome sequence and discovery of novel viruses by deep sequencing of small RNAs: A generic method for diagnosis, discovery and sequencing of viruses. Virology 388:1-7.

Lehnert, R. 2012. Living with plum pox? Good Fruit Grower. 63:26-27.

Levy, L., Damsteegt, V., and Welliver, R. 2000. First report of Plum pox virus (Sharka disease) in Prunus persica in the United States. Plant Dis. 84:202.

Loconsole, G., Saldarelli, P., Doddapaneni, H., Savino, V., Martelli, G. P., and Saponari, M. 2012. Identification of a single-stranded DNA virus associated with citrus chlorotic dwarf disease, a new member in the family Geminiviridae. Virology 432:162-172.

MacKenzie, D. J., McLean, M. A., Mukerji, S., and Green, M. 1997. Improved RNA extraction from woody plants for the detection of viral pathogens by reverse transcription-polymerase chain reaction. Plant Dis. 81:222-226.

Manjunath, K. L., Halbert, S. E., Ramadugu, C., Webb, S., and Lee, R. F. 2008. Detection of 'Candidatus Liberibacter asiaticus' in Diaphorina citri and its importance in the management of citrus huanglongbing in Florida. Phytopathology 98:387-396.

Marini, D. B., Zhang, Y.-P., Rowhani, A., and Uyemoto, J. K. 2002. Etiology and host range of a Closterovirus associated with plum bark necrosis-stem pitting disease. Plant Dis. 86:415-417.

Miller, W. A., Dinesh-Kumar, S. P., and Paul, C. P. 1995. Luteovirus gene expression. Curr. Rev. Plant Sci. 14:179-211. 
Murant, A. F. 1990. Dependence of groundnut rosette virus on its satellite RNA as well as on groundnut rosette assistor luteovirus for transmission by Aphis craccivora. J. Gen. Virol. 71:2163-2166.

Oliver, J. E., Freer, J., Andersen, R. L., Cox, K. D., Robinson, T. L., and Fuchs, M. 2009. Genetic diversity of Prunus necrotic ringspot virus isolates within a cherry orchard in New York. Plant Dis. 93:599-606.

Pantaleo, V., Saldarelli, P., Miozzi, L., Giampetruzzi, A., Gisel, A., Moxon, S., Dalmay, T., Bisztray, G., and Burgyan, J. 2009. Deep sequencing analysis of viral short RNAs from an infected Pinot noir grapevine. Virology 408:49-56.

Polston, J. E., McGovern, R. J., and Brown, L. G. 1999. Introduction of Tomato yellow leaf curl virus in Florida and implications for the spread of this and other geminiviruses of tomato. Plant Dis. 83:984-988.

Rodoni, B. 2009. The role of plant biosecurity in preventing and controlling emerging plant virus disease epidemics. Virus Res. 141:150-157.

Routh, G., Zhang, Y.-P., Saldarelli, P., and Rowhani, A. 1998. Use of degenerate primers for partial sequencing and RT-PCR-based assays of grapevine leafroll-associated viruses 4 and 5. Phytopathology 88: 1238-1243.

Rowhani, A., Uyemoto, J. K., Golino, D. A., and Martelli, G. P. 2005. Pathogen testing and certification of Vitis and Prunus species. Annu. Rev. Phytopathol. 43:261-278.

Salem, N., Golino, D. A., Falk, B. W., and Rowhani, A. 2008a. Identification and partial characterization of a new luteovirus associated with rose spring dwarf disease. Plant Dis. 92:508-512.

Salem, N. M., Miller, W. A., Rowhani, A., Golino, D. A., Moyne, A. L., and Falk, B. W. 2008b. Rose spring dwarf-associated virus has RNA structural and gene-expression features like those of Barley yellow dwarf virus. Virology 375:354-360.

Schneider, R. W., Hollier, C. A., Whitam, H. K., Palm, M. E., McKemy, J. M., Hernández, J. R., Levy, L., and DeVries-Paterson, R. 2005. First report of soybean rust caused by Phakopsora pachyrhizi in the continental United States. Plant Dis. 89:774.

Scorza, R., Hily, J.-M., Callahan, A., Malinowski, T., Cambra, M., Capote, N., Zagrai, I., Damsteegt, V., Briard, P., and Ravelonandro, M. 2007. Deregulation of plum pox resistant transgenic plum 'Honeysweet'. Acta Hortic. 738:669-673.

Stewart, L. R., Teplier, R. J., Todd, J. C., Jones, M. W., Cassone, B. J., Wijeratne, S., Wijeratne, A., and Redinbaugh, M. G. 2014. Viruses in maize and Johnsongrass in southern Ohio. Phytopathology 104:1360-1369.

Strand, L. L. 1999. Integrated pest management for stone fruits. Pages 2-4 in: UC IPM ANR publication No. 3389. University of California, Oakland, CA.

Sudarshana, M. R., Perry, K. L., and Fuchs, M. Grapevine red blotchassociated virus, an emerging threat to the grapevine industry. Phytopathology doi.org/10.1094/PHYTO-12-14-0369-FI

Tamura, K., Stecher, G., Peterson, D., Filipski, A., and Kumar, S. 2013. MEGA6: Molecular evolutionary genetics analysis version 6.0. Mol. Biol. Evol. 30:2725-2729.

Thompson, D., McCann, M., MacLeod, M., Lye, D., Green, M., and James, D. 2001. First report of plum pox Potyvirus in Ontario. Canada. Plant Dis. 85:97.

Uyemoto, J. K., Rowhani, A., Luvisi, D., and Krag, R. C. 2001. New closterovirus in 'Red globe' grape causes decline of grafted plants. Calif. Agric. 55:28-31.

Waterworth, H. E., and White, G. A. 1982. Plant introductions and quarantine: The need for both. Plant Dis. 66:87-90.

Zhang, Y., Singh, K., Kaur, R., and Qiu, W. 2011. Association of a novel DNA virus with the grapevine vein-clearing and vine decline syndrome. Phytopathology 101:1081-1090.

Zhang, Y.-P., Uyemoto, J. K., and Kirkpatrick, B. C. 1998. Analysis of doublestranded RNAs from cherry trees with stem pitting in California. Plant Dis. 82:871-874. 